\title{
Exploration of the material distribution of complex components in waste electrical and electronic equipment
}

\author{
Jandric A.*, Tran C.D., Beigl P., Micuda Z. and Salhofer S. \\ Institute of Waste Management, Department Water - Atmosphere - Environment, University of Natural Resources and Life Sciences, \\ Vienna, Austria
}

Received: 07/03/2018, Accepted: 10/07/2018, Available online: 26/09/2018

*to whom all correspondence should be addressed: e-mail: aleksander.jandric@gmail.com

https://doi.org/10.30955/gnj.002672

\begin{abstract}
Technological development combined with a rapid and global market penetration has led to high volumes of Waste Electrical and Electronic Equipment (WEEE). Simultaneously, the use-phase has become shorter resulting in an annual growth rate of WEEE between 3-5\%, which makes WEEE one of the fastest growing waste streams. The high metal content of WEEE has been a driving force for behind the expansion of recycling industry. However, during the de-pollution process, a certain type of components is sorted out, which due to their diversity in shape, size, and material composition, cannot be assigned to any homogenous material. These components can generally be classified as complex components and include Printed Circuit Boards (PCB), Hard Disk Drives, Power Supply Units, etc.

The aim of the present research is to provide an assessment of the material composition of complex components exemplified in more detail on PCBs. A set of minimal requirements has been developed in order to increase comparability of available data sets. Furthermore, a novel classification system has been designed for PCBs with according to the current recycling practices in EU. Finally, the paper provides a mapping of complex components with a particularly high content of precious metals and critical raw materials.
\end{abstract}

Keywords: PCB, precious metals, critical raw materials, trace metals, WEEE characterization.

\section{Introduction}

Intensive technological development of electrical and electronic devices combined with a rapid and global market penetration has led to high volumes of these products in the markets. At the same time, the use phase of many devices has become shorter, both leading to growing amount of end-of-life appliances including discarded materials and components from electronic equipment, here addressed as Waste Electrical and Electronic Equipment (WEEE). The amount of WEEE generated globally in 2014 was $48.1 \mathrm{Mt}$ with a growth rate of 3-5\% annually, for 2018 this amount will increase to $50 \mathrm{Mt}$ (Baldé et al., 2015).

WEEE is one of the fastest growing waste streams, containing both toxic and high market value materials. Driven by economic interests, informal recycler recovers valuable metals like copper, gold, and silver without concern on consequences from processes e.g. leaching (Wei and Liu, 2012). From these practices, WEEE has become one of the largest sources of heavy metals and organic pollutants in developing countries e.g. China, India and Nigeria, where this waste is being handled and disposed of in a non-environmental-friendly way (Chi et al., 2011).

Electrical and electronic equipment (EEE) contains an assortment of different metals, which have been a driving force for the development of both formal and informal recycling of WEEE. Base metals are providing elementary functions in EEE, e.g. mechanical stability as part of a device housing, component holders, screws, and similar. Output flows of pre-treatment process of high-grade WEEE consist of in general $30-40 \%$ of iron, $2-4 \%$ of aluminium, and $13-$ $17 \%$ of copper and precious metals (Bigum et al., 2012; Unger et al., 2017). These metals can be identified and quantified by simple material tests, i.e. magnet test, swimsink process, etc., according to their characteristic physical properties. However, EEE contains significant concentrations of precious metals, rare earth metals, and other highly valuable elements in comparably low concentrations in the order of several hundred ppm (Işıldar et al., 2016). Furthermore, besides their low concentrations, these elements are usually bound in exceptionally complex components such as Printed Circuit Boards (PCBs), connectors, batteries, capacitors, which makes their identification and quantification particularly challenging.

For approx. three decades, high metal content and consequent high recycling potential have been a driving force behind the interest to analyse complex components from WEEE. An epitome of complex components are PCBs due to the multitude of available types, a convoluted material composition containing over 20 different 
elements (c.f. Sorger et al., 2014). Furthermore, PCBs either contain components, e.g. central processing unit (CPU), switches, capacitors or serve as a mechanical support and connector, e.g. for Random Access Memory (RAM), which are regarded in scientific literature sometimes as separate components and sometimes as part of a PCB.

PCBs are complex material compounds with a high recycling potential due to their content of copper and precious metals. Beside valuable metals, PCBs also contain heavy metals, e.g. $\mathrm{Cd}, \mathrm{Pb}, \mathrm{Sb}, \mathrm{Sn}$, and other materials with a significant environmental impact, which classifies them as a "hazardous waste" according to the European WEEE Directive (EU, 2012). Throughout the literature, there are numerous results of PCBs material composition, which are resulting from various efforts to develop an accurate and comprehensible analytical method for this particular waste stream. Nevertheless, the results are highly scattered, and no definitive trends could have been determined so far solely based on the analysis of the results published in high impact scientific journals.

The aim of the present paper is to provide an extensive assessment of scientific literature regarding the material composition of complex components with a particular focus on challenges in determining the material composition of PCBs. The PCBs can be found in nearly all types of e-waste, which high proportions in electronic devices and lower ones in electric equipment (Huisman et al., 2007; Cui and Zhang, 2008). They are the most valuable material from e-waste recycling processes and therefore addressed in this paper in more detail. Section 2 addresses functions and criticality for the European Union of metals used in complex components from WEEE. Section 3 provides a critical overview of papers regarding the material composition of PCBs from the last thirty years. Based on available information from the scientific literature, section 4 provides a qualitative mapping of components containing trace metals and a quantitative overview of the material composition of PCBs and other complex components from WEEE.

\section{Management of WEEE and criticality of metals}

In the industrialised world, mainly in Europe, the treatment technology for WEEE has been developed significantly throughout the last 20 years. Today the European recycling industry has specific technology and capacity to treat the different categories of e-waste (large and appliances, small appliances, screens, cooling and freezing equipment and lamps), each of them posing specific challenges in terms of pollution control. It is significant to mention that $80 \%$ of ewaste is being exported to less developed countries where cheap labour and lack of regulation facilitate the treatment of waste regardless of adverse consequences (Khanna et al., 2014). However, with an exception of gold, the ability to determine material composition and subsequently to recycle the materials contained in small concentrations in WEEE is very limited. Primary causes for the following situation is high variety of available devices on the market, complex material structure of electronic devices, and relatively low market prices of primary materials.

A considerable policy shift took place in the European Union (EU) with the raw materials initiative "Meeting our critical needs for growth and jobs in Europe" prepared by Ad-hoc Working Group (Subgroup of the Raw Materials Initiative). The initiative is a key factor in the design of the recycling landscape in the EU. The core element of the Raw Materials Initiative is the definition of the criticality of raw materials for the EU with an aim to increase resource autonomy (Luidold et al., 2013). The first list of Critical Raw Material was created in 2011 and contained only 14 raw materials. However, since 2011 the list has been updated twice and expended. The current list was updated in 2017 and contains a list of 27 materials and material groups. The list contains both individual materials, e.g. Niobium, Tantalum, and material groups, i.e. PGM - platinum group metals, HREEE - heavy rare earth elements, and LREEE light rare earth elements.

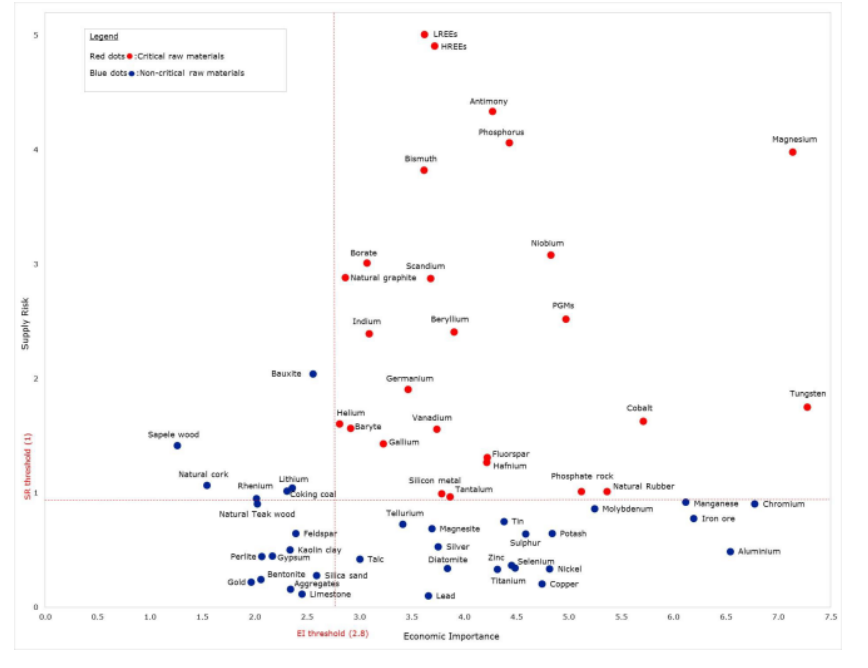

Figure 1. The current list of critical raw materials of the raw materials initiative (European Commission (European Commission, 2017)

The criticality of a material is determined by the European Commission (EC) is determined by two main factors: economic importance and supply risk. The economic importance is a factor, which provides characterises an impact of a material within the frame of EU manufacturing sectors. Furthermore, the economic importance is adjusted by the substitution index of economic importance (SIEI) with regard to the technical and cost performance of a substitute material for an individual application (European Commission,

2017).

The supply risk is a factor, which determines the risk of a supply interruption of the material in the EU. The assessment of governance performance and trade aspects of supply countries of the primary material determine the risk factor. The primary material producing countries are classified into two categories - the global suppliers and the countries from which the EU is sourcing the raw materials (European Commission, 2017).

The critical raw materials (CRM) are contained in electronic equipment in the devices and components that are 
intended to perform complex functions. In general, the increasing complexity of a device is directly proportional to an increasing complexity of material composition. Components containing the highest concentration of CRM are integrated circuits (ICS) and semi-conductors from PCBs, Hard Disk Drives (HDDs), LCD and LED displays, fluorescent lamps and other.

\section{Complex components in WEEE}

In the following section, the term complex components will be defined and subsequently a classification system for PCB will be proposed which should decrease the intricacy of chemical analyses of complex components from WEEE by providing a clear definition of the sample and categorizing them into classes with expected similar material compositions.

\subsection{Definition of complex components and their analytical challenges}

During the in-depth manual or mechanical disassembly as part of the pre-treatment process of WEEE, emerges a material stream, which due to the complex construction cannot be attributed to any homogenous output stream. Components containing this material stream can be classified as "complex components" (see Figure 2). The complex components represent assemblies of different parts and materials. They are highly versatile in their shape, size, and material composition and include components such as PCBs, HDDs, Power Supply Units, Optical Disc Drives, and other. Since they are usually made of many different elements, the determination of their material composition requires advanced analytical techniques.

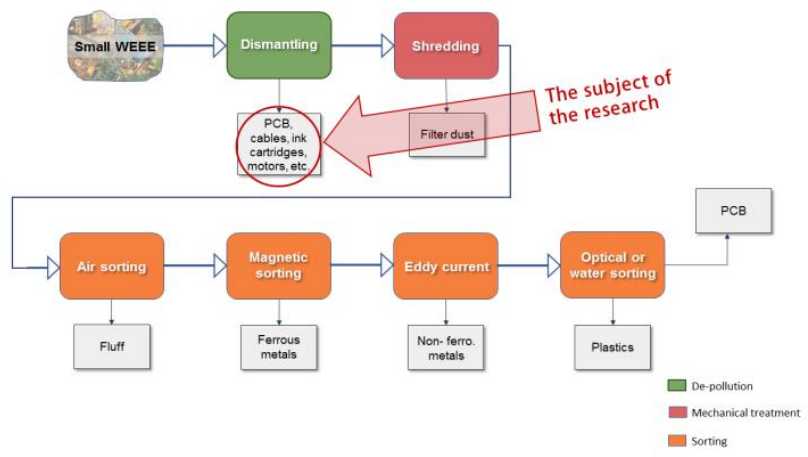

Figure 2. A general overview of pre-processing of WEEE (Jandric, 2017)

On account of high versatility, it is important to find a lowest common denominator for each type of complex components in order to increase for repeatability and reproducibility of the subsequent individual analyses. $A$ process of defining a sample containing complex component is exemplified in the further text on PCBs.

There is no single generally applicable material composition of the PCBs. In this sense, PCBs should be understood as an "umbrella term" for a variety of different component types, which perform a range of different functions and consequently are made of different materials. Therefore, PCBs from different WEEE should not be combined into a mixed sample. In addition, it is advised to refrain from stripping components from the PCB, since this procedure may vary in its efficiency and thereby have a significant influence on the outcome of the analysis. Also, the year of manufacture and any additional information about the analysed sample, e.g. size of the initial sample, whether the IC, capacitors, and other components have been stripped from the PCBs, significantly increases the value and the integrity of analysis. So far, the most frequently analysed types of PCBs, due to relatively high precious metal concentration, were $\mathrm{PCBs}$ from personal computers (PC) and the main PCB from mobile phones.

A further important aspect causing scattered results of material composition analyses is the fact that the analytical procedure has not been standardised with exception of elements defined by the European RoHS Directive, such as $\mathrm{Cd}, \mathrm{Cr} \mathrm{VI}, \mathrm{Hg}$, $\mathrm{Pb}$. So far, the prevailing analytical methods for the analysis of the material composition of PCBs are either based on a spectro-analytical procedure, i.e. inductively coupled plasma mass spectroscopy (ICP-MS) and optical emission spectrometry (ICP-OES), or on X-ray fluorescence (XRF). However, in many cases, the authors did not even indicate the method of analysis, which has been used for determining of the material composition, nor the type of sample preparation. Consequently, the evaluation of conducted analyses or establishing any trends in the material composition is near impossible and hence the scattered results in the scientific literature.

\subsection{Classification system for PCBs}

Based on the construction procedure, PCBs can be classified into three major groups: single-sided, doublesided and multi-layered. The single-sided boards have a conductive (copper) layer only on one side of the board, whereas double-sided have the conductive layers on both sides of the board. The multi-layered boards have two or more conductive layers separated by the non-conductive material (Ford and Cavette, 1996; Ono et al., 2010; Yamane et al., 2011; Kasper et al., 2011). More layers enable a denser population of the PCB with ICs, capacitors, diodes, and other components.

Another common classification of PCBs is based on the flame retardants applied in the non-metallic fraction (NMF), namely the "Flame Resistant 2" (FR-2) type and "Flame Resistant 4" (FR-4) type of PCBs. The FR-2 denotes a type of non-conductive substrate made of cellulose paper reinforced by phenol formaldehyde (Guo et al., 2009). The FR-2 substrates have a worldwide market share of approx. $12 \%$ (EPA, 2014). The FR-4 is a type of non-conductive substrate made of high-pressure flame-retardant woven glass reinforced by epoxy resin. Its main characteristics include near-zero water absorption, electrical insulation and resistance to heat, mechanical shock, and solvents (EPA, 2014). Because of these notable characteristics, the FR-4 substrates have a worldwide market share up to $70 \%$ of all types of laminates. The residual market share make composite substrates (5\%) and various other substrates (13\%) (cf. (Jing-ying et al., 2012; EPA, 2014). A classification of PCBs based on the substrate material is inadequate from 
the recycling point of view since the differentiation of laminates would be exceedingly difficult without employing additional analytical equipment and yet the differences in the metal content of PCBs would still stay unaddressed.

In the present research, the de facto classification of PCBs has been assessed from more than a dozen recycling companies from Austria, Germany, Spain, and Switzerland. Based on the retail prices of scrap PCBs, a classification system has been developed, which is both practical in terms of assignment of particular PCB to a corresponding category and also outlines the metal composition (GeldfuerAbfall, 2017; Beinhart, 2017; Computerplatinen.de, 2017). The categorisation and price ranges available are based on the nominal prices for PCBs available at the various home pages of e-waste dealing companies. However, the de facto prices of PCB may differ from these advertised at the corresponding homepage. An overview of the proposed classification of PCBs can be seen in Figure 3.

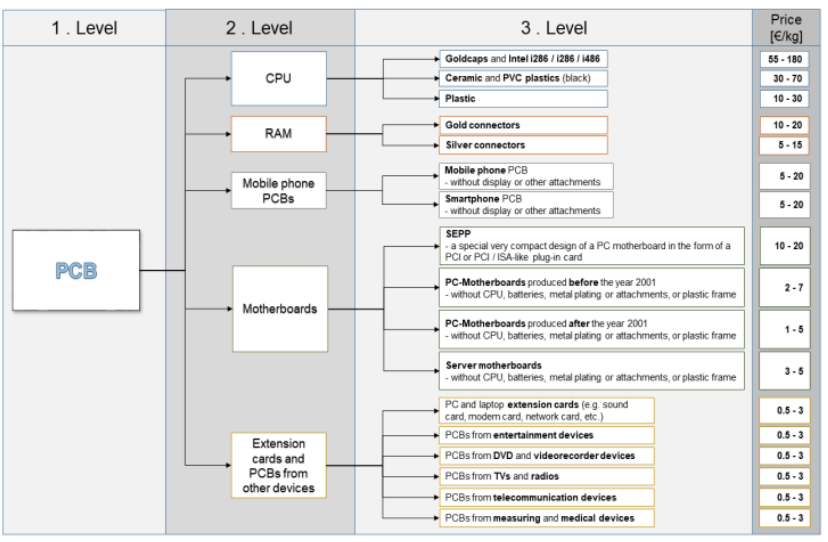

Figure 3. A classification of $\mathrm{PCBs}$ based on their price $[€ / \mathrm{kg}]$ on the scrap market in EU

The proposed classification of PCB, as shown in Figure 3, should be considered as a basis for future analytical procedures since it defines not only the subcategory of $P C B$ but also defines the term PCBs by providing a precise description which components should be included in the analysis.

After analysing the prices on the scrap market, it is apparent that PCBs from PCs and mobile phones (and smartphones) have the highest market value. Altohugh mobile phones and PCs also one of the fastest replacement cycles in relation to other WEEE, their market price is determined by the concentration of $\mathrm{Cu}, \mathrm{Au}$ and to a lesser extent of other metals. For these PCBs, the scrap market in the EU possesses highly developed categorisation as it differentiates between motherboards, random-access memory (RAM) with gold and silver connectors, and different types of central processing units (CPU) which are subsequently ranked also by varying prices. Less relevant types of PCBs include those from consumer electronics, such as TVs, radios, etc., which lack a subtle categorisation as it is the case with PCBs from Personal Computers (PCs) and mobile phones. Furthermore, this large group constituted of PCBs of various sizes and functions have very similar market prices. Rather than a signal for similar material compositions, this is much more indicative for the lack of information on their material composition.

\section{Material composition of PCBs and other complex components and qualitative mapping of trace metals from WEEE}

As determined in the previous chapter, the capacity to accurately determine material composition of PCBs is highly challenging. Nevertheless, the material composition of PCBs significantly influences the market price of this waste stream and thereby shapes the treatment procedures along the whole recycling process.

This section provides results of a comprehensive literature review. The first part of this section focuses on the quantification of metals in PCBs from mobile phones and $\mathrm{PCs}$, whereas the second part strives to pinpoint trace metals to components, i.e. capacitors, connectors, LCD displays etc. However, due to the high scattering of the data, at the present moment, it is not possible to determine precisely and accurately the material composition of individual components. For this reason, these data have been organised qualitatively rather than quantitatively.

\subsection{Evaluation of the literature regarding material composition of $P C B s$}

In this research, results have been evaluated from multielement analytical procedures regarding the material composition of $\mathrm{PCBs}$ published in $\mathrm{SCl}$ ranked journals analysing PCBs manufactured from the 1980s onwards. Besides $\mathrm{SCl}$ ranking, a set of minimal requirements has been established for the results of material composition to be considered for further assessment. The focus is set on the PCB types from PCs and mobile phones. The PCBs from other devices, i.e. PCBs from printers, laptops, DVD players, etc., have not been included in the evaluation due to the data scarcity, which thereby inhibits further statistical analysis. Furthermore, material compositions of mixed samples, i.e. samples containing several different types of PCBs, and material analyses of stripped PCBs have not been included in the assessment. The results of these analyses do not meet minimum requirements for repeatability and reproducibility of the analysis. Figure 4 gives an overview of published scientific papers on the subject of material composition of PCBs with particular focus on types of PCBs, analytical methods, and year of manufacture.

Approx. $40 \%$ of analyses carried out regarding the material composition of PCBs have been conducted on either on the mixed samples of PCBs or without any indication what type of PCBs have been analysed. These analyses are impossible to repeat or validate. Also, approx. $70 \%$ of available data do not have any information about the production year of analysed samples and additional $12 \%$ of data indicate only whether the PCBs have been produced before or after the year 2000. Out of an abundance of scientific literature on the material composition of PCBs, this leaves only approx. $15 \%$ of available data to try to determine any trends in change of material composition over time. Based on the 
currently available data, it is impossible to determine any trends in change of material composition of PCBs over time.

There are handful different analytical techniques applied for the determination of the material composition of PCBs, e.g. ICP based techniques (i.e. ICP-OES and ICP-MS), XRF, atomic absorption spectroscopy (AAS), thermogravimetric analysis (TGA). By comprehensive literature assessment, it can be concluded that the prevailing analytical technique covering approx. $60 \%$ of available data sets are the ICP techniques. The ICP is followed by XRF based analytical techniques covering approx. $10 \%$ of available data sets. Any other analytical approaches for the analysis of the material composition of $\mathrm{PCBs}$ are hitherto highly exceptional and cover less than $1 \%$ of available data sets and therefore have not been included in the analysis.
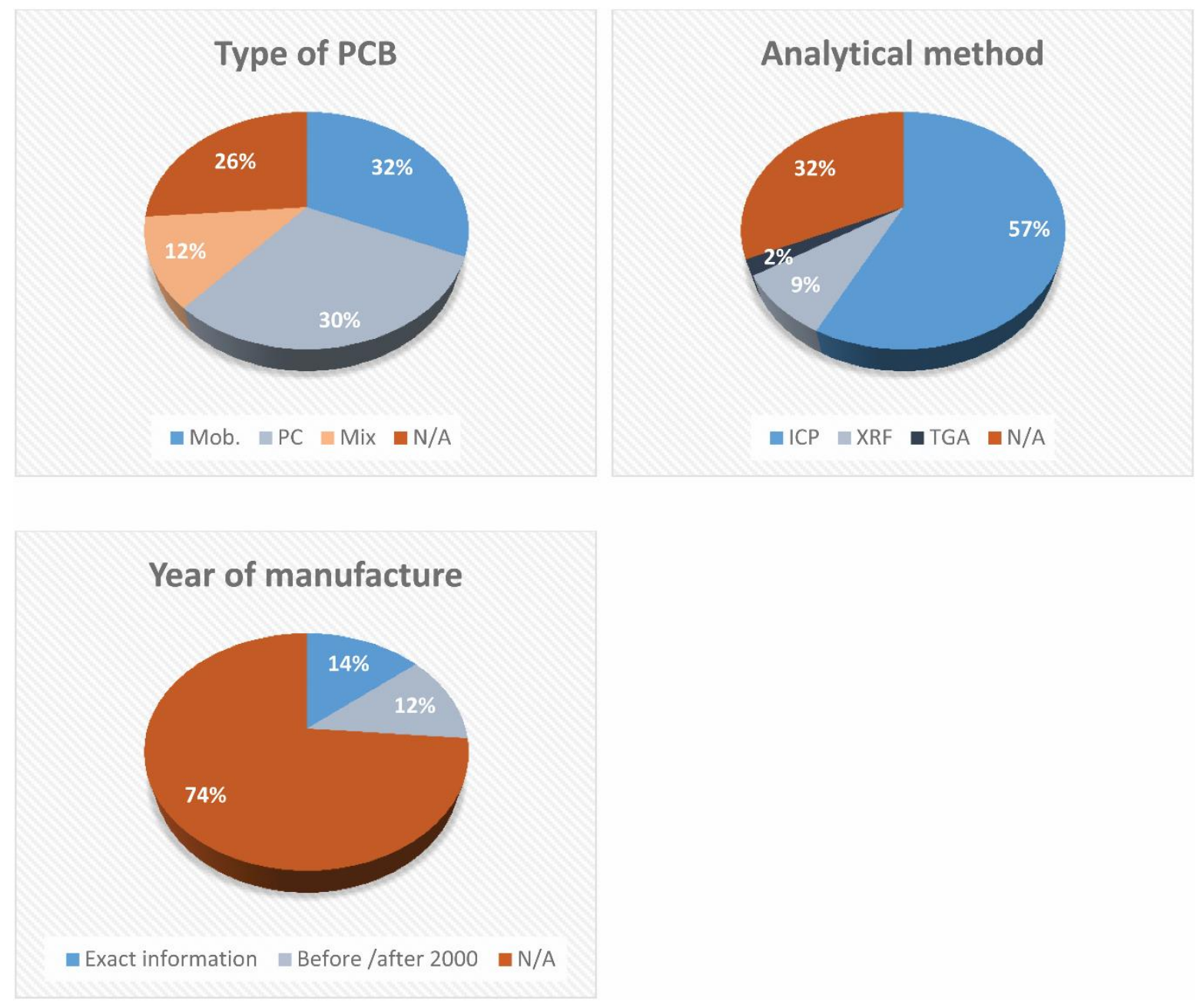

Figure 4. Overview of the scientific literature regarding material composition of PCBs $(n=57)$

After considering all of the restraining factors, from initial 57 scientific papers, only remaining 43 could have been used for further research.

\subsection{Material composition of PCBs}

In general, PCBs are made of three groups of materials: metals, plastics, and inorganic materials, such as glass fibres, ceramics, etc. Based on the availability of data, this paper focuses on metals. This group of materials has the highest recycling potential due to its economic value and poses the highest environmental threat if not treated properly. Metals in PCBs can be generally subdivided into base metals, with concentrations in the "[\%] range", and trace and precious metals, which are present in significantly smaller concentrations in the "[ppm] range".
Economically the most significant base metal contained in PCBs is copper, ranging between $6-40 \%$ of the total recycling revenues of PCB (c.f. Cui and Zhang, 2008). Furthermore, the concentrations of individual metal fractions fluctuate depending on both type of PCB and on the analytical method (see Figure 5). For example, the $\mathrm{Cu}$ concentration in PCBs from mobile phones (ICP) with a mean value of 34 wt.\% is significantly higher than concentration in PCBs from PCs (ICP), with a mean value of 23\%. Simultaneously, PCBs from PCs showed higher $\mathrm{Cu}$ concentrations if measured by XRF rather than with ICP. However, due to the insufficient data describing the conducted analyses, it is impossible to conclude whether the analytical method, year of manufacture or some other factor caused the difference in the results. 
In Figure $6 \mathrm{Au}$ concentrations for samples containing different types of PCBs are shown. Very similar as for $\mathrm{Cu}$ concentrations, the samples made of mobile phones PCBs have significantly higher concentrations than samples made of PCBs from PCs. The data variability is also the highest for samples containing mobile phones, which can partially be explained by the high diversification of products available in the market. However, the data insufficiency makes any conclusive outcome near impossible.

Table 1. Concentration of trace metals in PCBs [ppm]

\begin{tabular}{|c|c|c|c|c|c|c|c|c|}
\hline \multirow[b]{2}{*}{ [ppm] } & \multicolumn{4}{|c|}{ Mob } & \multicolumn{4}{|c|}{ PC } \\
\hline & ICP $(11 / 33)$ & Std. dev. & N/A (6/33) & Std. dev. & ICP (12/33) & Std. dev. & XRF (3/33) & Std. dev. \\
\hline $\mathrm{Ba}$ & 15000 & 3266 & 19333 & 2687 & 2523 & 1054 & & \\
\hline $\mathrm{Bi}$ & 695 & 599 & 539 & 356 & 160 & & & \\
\hline $\mathrm{Cr}$ & 1655 & 1163 & & & & & & \\
\hline Co & 915 & 552 & 298 & 161 & 10 & 0 & & \\
\hline $\mathrm{Mn}$ & & & & & 810 & 810 & & \\
\hline $\mathrm{Sb}$ & 472 & 72 & & & 1000 & & & \\
\hline $\mathrm{Pd}$ & 301 & 326 & 603 & 216 & 176 & 156 & 27 & \\
\hline $\mathrm{Au}$ & 898 & 581 & 1450 & 206 & 371 & 322 & 246 & 98 \\
\hline $\mathrm{Ag}$ & 1996 & 1209 & 13467 & 8486 & 577 & 384 & 694 & 7 \\
\hline
\end{tabular}

Table 2. Mapping of trace metals in comparatively high concentrations in complex components

\begin{tabular}{|c|c|c|c|c|c|c|}
\hline & $\begin{array}{c}\text { Ceramic } \\
\text { capacitors }\end{array}$ & Connectors & LCD displays & $\begin{array}{c}\text { Li-ion } \\
\text { batteris }\end{array}$ & $\begin{array}{c}\text { Ni-metal } \\
\text { hydride batt. }\end{array}$ & Magnets \\
\hline & $\begin{array}{c}\text { (Prabaharan et } \\
\text { al., 2016) }\end{array}$ & $\begin{array}{c}\text { (Ueberschaar et } \\
\text { al., 2017) }\end{array}$ & $\begin{array}{c}\text { (Zhang et al., } \\
\text { 2017) }\end{array}$ & $\begin{array}{l}\text { (Sommer et } \\
\text { al., 2015) }\end{array}$ & $\begin{array}{c}\text { (Meshram et } \\
\text { al., 2017) }\end{array}$ & $\begin{array}{c}\text { (München and Veit, } \\
\text { 2017) }\end{array}$ \\
\hline & \multicolumn{6}{|c|}{ [ppm] } \\
\hline Chrome(Cr) & 3.000 & - & 4.600 & - & - & 10.000 \\
\hline Cobalt (Co) & - & - & - & $\begin{array}{r}25.000- \\
140.000\end{array}$ & 49.000 & - \\
\hline Gallium (Ga) & - & $15.000-30.000$ & - & - & - & - \\
\hline $\begin{array}{l}\text { Germanium } \\
(\mathrm{Ge})\end{array}$ & - & 1.000 & - & - & - & - \\
\hline Gold $(\mathrm{Au})$ & 10 & $7.000-30.000$ & - & - & - & - \\
\hline Indium (In) & - & - & 80.000 & - & - & - \\
\hline $\begin{array}{l}\text { Magnesium } \\
\quad(\mathrm{Mg})\end{array}$ & - & - & - & - & - & - \\
\hline Palladium (Pd) & 50 & - & - & - & - & - \\
\hline Platinum (Pt) & - & - & - & - & - & - \\
\hline REE & - & - & - & - & 180.000 & 210.000 \\
\hline Silicon (Si) & - & - & - & - & - & - \\
\hline Silver (Ag) & 130 & $1.000-3.000$ & - & - & - & - \\
\hline $\operatorname{Tin}(\mathrm{Sb})$ & - & - & - & - & - & - \\
\hline
\end{tabular}

Table 1 illustrates trace metals which are contained in low concentrations and their values are expressed in ppm. Since their absolute quantity in PCBs is small, there are several factors influencing the results of a material analysis, such as type/model of analysed PCB, method, and equipment used for the analysis, a focus of the analysis and size of the particle size pre-treated PCBs.

Furthermore, it becomes clear that precious metals, similarly to $\mathrm{Cu}$ fraction, have very large dispersion. However, from the material analyses conducted and published, it is possible to determine a reasonable material concentration range present in the PCBs. This in mind, gold fraction ranges between 100 and 500 ppm with the mean value of approx. 370 ppm for the PCB from PCs, whereas the gold concentration in $\mathrm{PCBs}$ from mobile phone range between 400 and 1400 ppm with a mean value of approx.
$900 \mathrm{ppm}$. Besides higher concentration, the gold fraction from a mobile phone shows also the very high rate of scattering. Besides differences in analytical method and samples size, an additional cause for the data variability of Au fraction in mobile phone samples can be explained by extraordinary technological development resulting in higher differences between different models and between different manufacturers.

4.3. Complex components with high concentrations of precious metals and critical raw materials

Beside PCBs, there is number of different complex components originating from WEEE, which are also prone to the significant influence of technological development. However, due to their extremely high variety of the shapes, sizes, and functions, the available data in the scientific literature regarding their material composition is even 
more inconclusive than it is the case with PCBs. Even though based on the currently available data it is not possible to obtain a reliable total material composition of complex component, by focusing on specific parts and materials it is possible to single out certain parts of complex components, i.e. capacitors, magnets, batteries, etc., with comparatively high concentrations of precious metals and CRM (see Table 2).

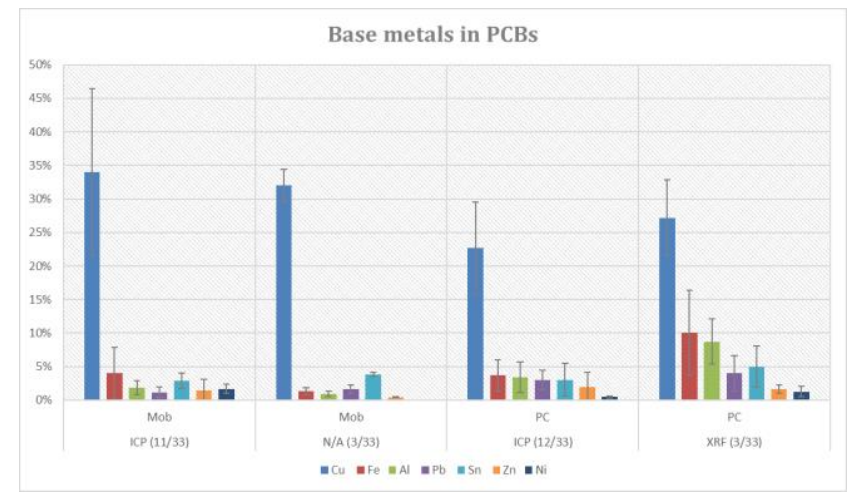

Figure 5. Concentrations of base metals in PCBs

However, due to the inconclusiveness of the research, the listed concentrations should be understood as a binary matrix - it provides information whether the complex component contains or does not contain a particular metal.

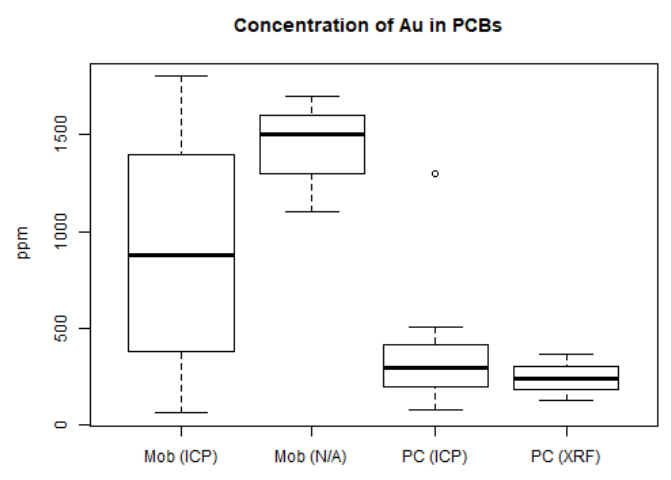

Figure 6. Concentrations of $\mathrm{Au}$ in PCBs

\section{Conclusion}

Despite an evident plenitude of scientific papers regarding the material composition of complex components from WEEE, a majority of these datasets have been rejected for not fulfilling even minimal scientific requirements. In the past, many papers have been published offering different, even opposing results without an appropriate description of the sample or applied analytical procedure.

Although the material composition of complex components has been in the focus of multi-elemental chemical analyses since 1980-is, no standardized analytical procedure for complex components or for any type of WEEE has been developed so far. Up to this day, as guidelines for the analysis of WEEE are used standards for soil samples analyses or standardization for waste samples in general, usually containing also biological materials.
Based on the results obtained from the literature assessment, the PCBs from mobile phones have a concentration of $\mathrm{Cu}$ exceeding the $30 \mathrm{wt} . \%$ on average which is significantly higher than 22-26 wt.\% Cu concentration in the PCBs from PCs. In addition, regardless of the analytical procedure, Au concentration in the PCBS from mobile phones is higher than Au concentration in the PCBs from PCs, ranging between 900 ppm and 400 ppm on average respectively.

Over time a need for a fundamental change in approach to analytics of WEEE became apparent. In a time period where electronic equipment experience rapid technological development and increasing complexity, a demand for critical raw materials require identification, quantification, and finally recycling of elements in exceedingly small quantities from convoluted sample matrices. This puts a heavy strain on the current analytical practice of waste electronics. The needs of the recycling industry have outgrown simple quantification of $A u$ in PCBs and challenge the waste analytics for a robust, easily validated, and reliable analytical approach for the analysis material composition.

Improvement in the analytics of waste electronics would have a significant influence on the recycling landscape enabling the higher efficiency of scrap and secondary material markets, but also allowing more decentralised recycling of waste electronics. Furthermore, it can be expected that a robust data basis would significantly increase the potential for development of new recycling technologies.

\section{References}

Baldé C.P., Wang F., Kuehr R. and Huisman J. (2015), The Global Ewaste Monitor - 2014, United Nations University, IAS SCYCLE, Bonn, Germany.

Behnamfard A., Salarirad M.M. and Veglio F. (2013), Process development for recovery of copper and precious metals from waste printed circuit boards with emphasize on palladium and gold leaching and precipitation, Waste Management, 33(11), 2354-2363.

Beinhart H. (2017), Platinen Handel Beinhart - Ankaufspreise PCSchrott. URL: https://www.platinen-handel.at/ankaufwien/e-schrott.php.

Bigum M., Brogaard L. and Christensen T.H. (2012), Metal recovery from high-grade WEEE: A life cycle assessment, Journal of Hazardous Materials, 207-208, 8-14.

Birloaga I., De Michelis I., Ferella F., Buzatu M.and Vegliò F. (2013), Study on the influence of various factors in the hydrometallurgical processing of waste printed circuit boards for copper and gold recovery, Waste Management, 33(4), 935-941.

Camelino S., Rao J., Padilla R.L. and Lucci R. (2015), Initial studies about gold leaching from printed circuit boards (PCB's) of waste cell phones. Procedia Materials Science, 9, 105-112.

Chen S., Yang Y., Liu C., Dong F. and Liu B. (2015), Column bioleaching copper and its kinetics of waste printed circuit boards (WPCBs) by Acidithiobacillus ferrooxidans, Chemosphere, 141, 162-168. 
Chi X., Streicher-Porte M., Wang M.Y.L. and Reuter M.A. (2011), Informal electronic waste recycling: A sector review with special focus on China, Waste Management, 31(4), 731-742.

Computerplatinen (2017), Computerplatinen.de URL: http:// www.computerplatinen.de/elektronik-recyclingpreise/schrott-computer-platinen.php [accessed 11 November 2016].

Cucchiella F., D'Adamo I., Rosa P. and Terzi S. (2016), Automotive printed circuit boards recycling: an economic analysis, Journal of Cleaner Production, 121, 130-141.

Cui J. and Zhang L. (2008), Metallurgical recovery of metals from electronic waste: a review, Journal of Hazardous Materials, 158(2-3), 228-256.

De Marco I., Caballero B.M., Chomón M.J., Laresgoiti M.F., Torres A., Fernández G. and Arnaiz S. (2008), Pyrolysis of electrical and electronic wastes. Journal of Analytical and Applied Pyrolysis, 82(2), 179-183.

EPA U. (2014), Flame Retardants in Printed Circuit Boards: Chapter 2, United States Environmental Protection Agency.

Ernst T., Popp R., Wolf M. and van Eldik R. (2003), Analysis of ecorelevant elements and noble metals in printed wiring boards using AAS, ICP-AES and EDXRF, Analytical and Bioanalytical Chemistry, 375(6), 805-814.

EU (2012), Directive 2012/19/EU of the European Parliament and of the Council of 4 July 2012 on waste electrical and electronic equipment (WEEE).

European Commission (2017). Report on Critical Raw Materials for the EU - The communication on the list of critical raw materials 2017.

Evangelopoulos P., Kantarelis E. and Yang W. (2015), Investigation of the thermal decomposition of printed circuit boards (PCBs) via thermogravimetric analysis (TGA) and analytical pyrolysis (Py-GC/MS), Journal of Analytical and Applied Pyrolysis, 115, 337-343.

Evangelopoulos P., Kantarelis E. and Yang W. (2017), Experimental investigation of the influence of reaction atmosphere on the pyrolysis of printed circuit boards, Applied Energy.

Ford D.N. and Cavette C. (1996), Printed Circuit Boards - How Products are Made. Gale Research Inc.

Fujita T., Ono H., Dodbiba G. and Yamaguchi K. (2014), Evaluation of a recycling process for printed circuit board by physical separation and heat treatment, Waste Management, 34(7), 1264-1273.

GeldfuerAbfall (2017), Geld für Abfall - Ankauf Elektroschrott [online]. Geld für Abfall. URL: http:// www.geldfuerabfall.com/index.php/ankauf-elektroschrott [accessed 11 November 2016].

Gongming Z., Luo Z. and Zhai X. (2007), Experimental Study on Metal Recycling from Waste PCB. Conference on Sustainable Solid Waste Management. Chennai, India.

Guo J., Guo J. and Xu Z. (2009), Recycling of non-metallic fractions from waste printed circuit boards: a review. Journal of Hazardous Materials, 168(2-3), 567-590.

Hadi P., Xu M., Lin C.S.K., Hui C.-W. and McKay G. (2015), Waste printed circuit board recycling techniques and product utilization. Journal of Hazardous Materials, 283, 234-243.

Holgersson S., Steenari B.-M., Björkman M. and Cullbrand K. (2017), Analysis of the metal content of small-size Waste Electric and Electronic Equipment (WEEE) printed circuit boards-part 1: Internet routers, mobile phones and smartphones. Resources, Conservation and Recycling.
Huisman J., Delgado C., Magalini F., Kuehr R. and Maurer C. (2007), 2008 Review of Directive 2002/96 on Waste Electrical and Electronic Equipment (WEEE) - Final report.

Huisman J., Magalini F., Kuehr R., Maurer C., Ogilvie S., Poll J., Delgado C., Artim E., Szlezak J. and Stevels A. (2008), Review of Directive 2002/96 on Waste Electrical and Electronic Equipment (WEEE), Final Report. United Nations University.

Işıldar, A., van de Vossenberg J., Rene E.R., van Hullebusch E.D. and Lens P.N.L. (2016), Two-step bioleaching of copper and gold from discarded printed circuit boards (PCB). Waste Management, 57, 149-157.

Jandric A. (2017) Material Composition of Complex Compoenents in WEEE. Institute of Waste Management. University of Natural Resources and Applied Sciences Vienna, Vienna.

Jing-ying L., Xiu-li X. and Wen-quan L. (2012), Thiourea leaching gold and silver from the printed circuit boards of waste mobile phones. Waste Management, 32(6), 1209-1212.

Kasper A.C., Berselli G.B., Freitas B.D., Tenorio J.A., Bernardes A.M. and Veit H.M. (2011), Printed wiring boards for mobile phones: characterization and recycling of copper. Waste Management, 31(12), 2536-2545.

Khanna R., Cayumil R., Mukherjee P.S. and Sahajwalla V. (2014), A novel recycling approach for transforming waste printed circuit boards into a material resource - sciencedirect. Procedia Environmental Sciences, 21, 42-54.

Kim B.-S., Lee J.-C., Seo S.-P., Park Y.-K. and Sohn H.Y. (2004), A process for extracting precious metals from spent printed circuit boards and automobile catalysts. Journal of Management, 56(12), 55-58.

Le H., Yamasue E., Okumura H. and Ishihara K. (2013), MEMRECS-A sustainable view for metal recycling from waste printed circuit boards. Journal of Environmental Protection, 4(8), 803-810.

Luidold S., Kozlik M., Raith J., Janisch A., Moser P. and Treimer R. (2013), Kritische Rohstoffe für Die Hochtechnologieanwendung in Österreich. Bundesministerium für Verkehr, Innovation und Technologie.

Meshram P., Somani H., Pandey B.D., Mankhand T.R., Deveci H. and Abhilash (2017) Two stage leaching process for selective metal extraction from spent nickel metal hydride batteries, Journal of Cleaner Production, 157, 322-332.

München D.D. and Veit H.M. (2017), Neodymium as the main feature of permanent magnets from hard disk drives (HDDs), Waste Management, 61, 372-376.

Neto I.F.F., Sousa C.A., Brito M.S.C.A., Futuro A.M. and Soares H.M.V.M. (2016), A simple and nearly-closed cycle process for recycling copper with high purity from end life printed circuit boards, Separation and Purification Technology, 164, 19-27.

Oguchi M., Murakami S., Sakanakura H., Kida A. and Kameya T. (2011), A preliminary categorization of end-of-life electrical and electronic equipment as secondary metal resources, Waste Management, 31(9-10), 2150-2160.

Ogunniyi I.O., Vermaak M.K.G. and Groot D.R. (2009), Chemical composition and liberation characterization of printed circuit board comminution fines for beneficiation investigations, Waste Management, 29(7), 2140-2146.

Oishi T., Koyama K., Alam S., Tanaka M. and Lee J.C. (2007), Recovery of high purity copper cathode from printed circuit boards using ammoniacal sulfate or chloride solutions, Hydrometallurgy, 89(1), 82-88. 
Ono H., Dodbiba G. and Fujita T. (2010) Copper recovery from printed circuit board by carbonization. International journal of the Society of Materials Engineering for Resources, 17(1), 5357.

Ortuño N., Moltó J., Egea S., Font R. and Conesa J.A. (2013), Thermogravimetric study of the decomposition of printed circuit boards from mobile phones, Journal of Analytical and Applied Pyrolysis, 103, 189-200.

Park Y.J. and Fray D.J. (2009), Recovery of high purity precious metals from printed circuit boards, Journal of Hazardous Materials, 164(2), 1152-1158.

Prabaharan G., Barik S.P. and Kumar B. (2016), A hydrometallurgical process for recovering total metal values from waste monolithic ceramic capacitors, Waste Management, 52, 302-308.

Sommer P., Rotter V.S. and Ueberschaar M. (2015), Battery related cobalt and REE flows in WEEE treatment, Waste Management, 45, 298-305.

Sorger C., Stuhlpfarrer P., Luidold S. and Antrekowitsch H. (2014), The effects of the pyrolysis of electronic scrap on further metallurgical treatment, BHM Berg- und Hüttenmännische Monatshefte, 159(7), 306-307.

Sum E.Y.L. (1991), The recovery of metals from electronic scrap, Journal of Management, 43(4), 53-61.

Ueberschaar M., Otto S.J. and Rotter V.S. (2017), Challenges for critical raw material recovery from WEEE - The case study of gallium, Waste Management, 60, 534-545.

Unger N., Beigl P., Höggerl G. and Salhofer S. (2017), The greenhouse gas benefit of recycling waste electrical and electronic equipment above the legal minimum requirement: An Austrian LCA case study, Journal of Cleaner Production, 164(Supplement C), 1635-1644.

Veit, H.M., de Pereira C.C. and Bernardes A.M. (2002), Using mechanical processing in recycling printed wiring boards, Journal of Management, 54(6), 45-47.

Wei, L. and Liu Y. (2012), Present Status of e-waste Disposal and Recycling in China. The Seventh International Conference on Waste Management and Technology (ICWMT 7), Procedia Environmental Sciences, Beijing, China, pp. 506-514.

Williams P.T. (2010) Valorization of printed circuit boards from waste electrical and electronic equipment by pyrolysis, Waste and Biomass Valorization, 1(1), 107-120.

Xiu, F.-R., Qi Y. and Zhang F.-S. (2015), Leaching of Au, Ag, and Pd from waste printed circuit boards of mobile phone by iodide lixiviant after supercritical water pre-treatment, Waste Management, 41, 134-141.

Yamane, L.H., de Moraes V.T., Espinosa D.C. and Tenorio J.A. (2011), Recycling of WEEE: characterization of spent printed circuit boards from mobile phones and computers, Waste Management, 31(12), 2553-2558.

Yang H., Liu J. and Yang J. (2011), Leaching copper from shredded particles of waste printed circuit boards, Journal of Hazardous Materials, 187(1), 393-400.

Yang Y., Chen S., Li S., Chen M., Chen H. and Liu B. (2014), Bioleaching waste printed circuit boards by Acidithiobacillus ferrooxidans and its kinetics aspect, Journal of Biotechnology, 173, 24-30.

Yazici E.Y. and Deveci H. (2013), Extraction of metals from waste printed circuit boards (WPCBs) in $\mathrm{H} 2 \mathrm{SO} 4-\mathrm{CuSO} 4-\mathrm{NaCl}$ solutions, Hydrometallurgy, 139, 30-38.
Zhang G., Wang H., Zhang T., Yang X., Xie W. and He Y. (2016a), Removing inorganics from nonmetal fraction of waste printed circuit boards by triboelectric separation, Waste Management, 49, 230-237.

Zhang L., Wu B., Chen Y. and Xu Z. (2017), Treatment of liquid crystals and recycling indium for stripping product gained by mechanical stripping process from waste liquid crystal display panels, Journal of Cleaner Production, 162, 1472-1481.

Zhang S. and Forssberg E. (1997), Mechanical separation-oriented characterization of electronic scrap, Resources, Conservation and Recycling, 21(4), 247-269.

Zhang W., Ren J., Liu S. and Yuan Z. (2016b), Mechanism and clean procedure to extract gold from printed circuit board, Procedia Environmental Sciences, 31, 171-177. 
Annex I

\begin{tabular}{|c|c|c|c|c|c|c|c|c|c|c|c|c|c|c|c|c|c|c|c|c|c|}
\hline Source & $\mathrm{Cu}$ & $\mathrm{Fe}$ & Al & $\mathrm{Pb}$ & Sn & $\mathrm{Zn}$ & $\mathrm{Ni}$ & $\mathrm{Ba}$ & $\mathrm{Bi}$ & $\mathrm{Cr}$ & Co & $\mathrm{Mn}$ & Sb & $\mathrm{Ti}$ & Pd & $\mathrm{Au}$ & $\mathrm{Ag}$ & $\begin{array}{c}\text { Sample } \\
\text { preparation }\end{array}$ & Method & Year & $\begin{array}{c}\text { Type } \\
\text { of PCB }\end{array}$ \\
\hline (Sum, 1991) & $20.0 \%$ & $8.0 \%$ & $2.0 \%$ & $2.0 \%$ & $4.0 \%$ & $1.0 \%$ & $2.0 \%$ & $*$ & $*$ & $*$ & $*$ & $*$ & 4,000 & $*$ & 100 & 1,000 & 2,000 & $\mathrm{~N} / \mathrm{A}$ & N/A & 1991 & N/A \\
\hline $\begin{array}{c}\text { (Zhang and } \\
\text { Forssberg, } \\
\text { 1997) } \\
\end{array}$ & $10.0 \%$ & * & $7.0 \%$ & $1.2 \%$ & * & $1.6 \%$ & $0.9 \%$ & $*$ & $*$ & * & $*$ & * & $*$ & $*$ & * & 300 & 100 & Thiourea & ICP & 1997 & $\begin{array}{l}\mathrm{PCB}- \\
\mathrm{PC}\end{array}$ \\
\hline $\begin{array}{c}\text { (Guo et al., } \\
\text { 2009) }\end{array}$ & $26.8 \%$ & $5.3 \%$ & $4.7 \%$ & $*$ & $1.0 \%$ & $1.5 \%$ & $0.5 \%$ & 200 & $*$ & 500 & $*$ & 4,700 & $*$ & 34,000 & * & 100 & 3,300 & N/A & N/A & 1998 & N/A \\
\hline $\begin{array}{c}\text { (Veit et al., } \\
\text { 2002) }\end{array}$ & $23.5 \%$ & $0.1 \%$ & $1.6 \%$ & $1.0 \%$ & $2.5 \%$ & $0.1 \%$ & $0.2 \%$ & $*$ & $*$ & $*$ & $*$ & $*$ & $*$ & $*$ & $*$ & $*$ & 300 & $\begin{array}{c}\text { Tetra- } \\
\text { bromoethane }\end{array}$ & $*$ & 2002 & $\begin{array}{l}\text { PCB - } \\
P C\end{array}$ \\
\hline $\begin{array}{l}\text { (Ernst et al., } \\
\text { 2003) }\end{array}$ & $17.2 \%$ & $*$ & $*$ & $3.5 \%$ & $*$ & $*$ & $1.1 \%$ & $*$ & $*$ & 1,040 & $*$ & $*$ & 2,690 & $*$ & 95 & 191 & 1,420 & Aqua regia & AAS & 2003 & $\begin{array}{c}\text { PCB - } \\
\text { m. } \\
\text { phone }\end{array}$ \\
\hline $\begin{array}{c}\text { (Kim et al., } \\
2004)\end{array}$ & $15.6 \%$ & $1.4 \%$ & $*$ & $1.4 \%$ & $3.2 \%$ & $0.2 \%$ & $0.3 \%$ & $*$ & $*$ & $*$ & $*$ & $*$ & $*$ & $*$ & 100 & 420 & 1,240 & Pyrolysis & $*$ & 2004 & $\begin{array}{l}\text { PCB - } \\
\text { mix }\end{array}$ \\
\hline $\begin{array}{c}\text { (Park and } \\
\text { Fray, 2009) }\end{array}$ & $20.0 \%$ & $0.8 \%$ & * & $2.0 \%$ & $4.0 \%$ & $4.5 \%$ & $2.0 \%$ & $*$ & $*$ & $*$ & $*$ & $*$ & $*$ & $*$ & 100 & 1,000 & 2,000 & Aqua regia & ICP-MS & 2005 & $\begin{array}{l}\text { PCB - } \\
\text { mix }\end{array}$ \\
\hline $\begin{array}{c}\text { (Ogunniyi et } \\
\text { al., 2009) }\end{array}$ & $17.9 \%$ & $0.2 \%$ & $4.8 \%$ & $4.2 \%$ & $5.3 \%$ & $2.2 \%$ & $1.6 \%$ & $*$ & $*$ & $*$ & $*$ & $*$ & $*$ & $*$ & 300 & 400 & 13 & N/A & N/A & 2006 & N/A \\
\hline $\begin{array}{l}\text { (Hadi et al., } \\
\text { 2015) }\end{array}$ & $7.0 \%$ & $17.0 \%$ & $7.0 \%$ & $0.3 \%$ & $0.3 \%$ & $3.0 \%$ & $2.3 \%$ & $*$ & 50 & 20 & $*$ & $*$ & $*$ & $*$ & $*$ & 300 & 3,000 & N/A & N/A & 2006 & $\begin{array}{l}\text { PCB - } \\
\text { mix }\end{array}$ \\
\hline $\begin{array}{l}\text { (Hadi et al., } \\
\text { 2015) }\end{array}$ & $27.0 \%$ & $2.0 \%$ & $1.0 \%$ & $3.0 \%$ & $3.0 \%$ & $0.5 \%$ & $0.2 \%$ & $*$ & 500 & 1,000 & $*$ & $*$ & $*$ & $*$ & $*$ & 1,000 & 400 & N/A & N/A & 2006 & $\begin{array}{c}\text { PCB - } \\
\text { mix }\end{array}$ \\
\hline $\begin{array}{c}\text { (Oishi et al., } \\
\text { 2007) }\end{array}$ & $26.0 \%$ & $3.4 \%$ & $3.2 \%$ & $3.0 \%$ & $4.9 \%$ & $2.6 \%$ & $1.5 \%$ & $*$ & 30 & $*$ & 580 & 1,100 & 1,600 & $*$ & $*$ & $*$ & 630 & Aqua regia & ICP-OES & 2007 & N/A \\
\hline $\begin{array}{l}\text { (Huisman et } \\
\text { al., 2008) }\end{array}$ & $14.8 \%$ & $15.2 \%$ & $7.1 \%$ & $1.5 \%$ & $1.4 \%$ & $1.4 \%$ & $0.4 \%$ & $*$ & 24 & 576 & $*$ & $*$ & 662 & $*$ & 38 & 94 & 586 & N/A & N/A & 2007 & $\begin{array}{l}\text { PCB - } \\
\text { mix }\end{array}$ \\
\hline $\begin{array}{l}\text { (Cucchiella } \\
\text { et al., 2016) }\end{array}$ & $18.8 \%$ & $0.2 \%$ & $0.0 \%$ & $0.7 \%$ & $1.8 \%$ & $*$ & $0.7 \%$ & $*$ & $*$ & $*$ & $*$ & $*$ & $*$ & $*$ & $*$ & 4,200 & 900 & N/A & N/A & 2007 & N/A \\
\hline $\begin{array}{l}\text { (Gongming } \\
\text { et al., 2007) }\end{array}$ & $24.7 \%$ & $0.2 \%$ & $1.6 \%$ & $0.6 \%$ & $2.3 \%$ & $0.1 \%$ & $0.1 \%$ & 1,600 & $*$ & 250 & $*$ & 120 & 19,700 & 900 & 27 & 76 & 242 & N/A & N/A & 27 & N/A \\
\hline $\begin{array}{c}\text { (de Marco et } \\
\text { al., 2008) }\end{array}$ & $36.4 \%$ & $3.9 \%$ & $8.7 \%$ & $3.8 \%$ & $4.6 \%$ & $3.5 \%$ & $0.5 \%$ & $*$ & $*$ & $*$ & $*$ & $*$ & $*$ & $*$ & 100 & 300 & 1,600 & pyrolysis & $I C P$ & 2008 & $\begin{array}{l}\text { PCB - } \\
\text { mix }\end{array}$ \\
\hline
\end{tabular}




\begin{tabular}{|c|c|c|c|c|c|c|c|c|c|c|c|c|c|c|c|c|c|c|c|c|c|}
\hline $\begin{array}{l}\text { (Ogunniyi et } \\
\text { al., 2009) }\end{array}$ & $23.5 \%$ & $1.2 \%$ & $1.3 \%$ & $1.0 \%$ & $1.5 \%$ & $1.5 \%$ & $2.4 \%$ & $*$ & * & $*$ & $*$ & $*$ & $*$ & $*$ & 294 & 570 & 3,301 & Aqua regia & ICP-OES & 2009 & $\begin{array}{c}\text { PCB - } \\
\text { m. } \\
\text { phone }\end{array}$ \\
\hline $\begin{array}{l}\text { (Park and } \\
\text { Fray, 2009) }\end{array}$ & $16.0 \%$ & $5.0 \%$ & $5.0 \%$ & $2.0 \%$ & $3.0 \%$ & $1.0 \%$ & $1.0 \%$ & $*$ & * & $*$ & $*$ & $*$ & $*$ & $*$ & 100 & 250 & 1,000 & Aqua regia & $\mathrm{ICP}$ & 2009 & $\begin{array}{l}\text { PCB - } \\
\text { mix }\end{array}$ \\
\hline $\begin{array}{l}\text { (Holgersson } \\
\text { et al., 2017) }\end{array}$ & $34.3 \%$ & $0.7 \%$ & $1.9 \%$ & $0.4 \%$ & $1.9 \%$ & $0.5 \%$ & $1.2 \%$ & $*$ & 40 & 865 & * & $*$ & 543 & $*$ & 119 & 1,051 & 2,640 & Aqua regia & ICP-SFS & 2010 & $\begin{array}{c}\text { PCB - } \\
\text { m. } \\
\text { phone }\end{array}$ \\
\hline $\begin{array}{c}\text { (Williams, } \\
\text { 2010) }\end{array}$ & $16.7 \%$ & $1.1 \%$ & $2.2 \%$ & $2.2 \%$ & $*$ & $0.1 \%$ & $0.1 \%$ & $*$ & $*$ & 270 & $*$ & $*$ & $*$ & $*$ & $*$ & 200 & 800 & Pyrolysis & $\mathrm{ICP}$ & 2010 & $\begin{array}{l}\text { PCB - } \\
\text { mix }\end{array}$ \\
\hline $\begin{array}{c}\text { (Williams, } \\
\text { 2010) }\end{array}$ & $26.0 \%$ & $16.0 \%$ & $10.5 \%$ & $7.7 \%$ & $*$ & $1.5 \%$ & $2.4 \%$ & $*$ & $*$ & 120 & $*$ & $*$ & $*$ & $*$ & $*$ & $*$ & 15,020 & Pyrolysis & $\mathrm{ICP}$ & 2010 & $\begin{array}{l}\text { PCB - } \\
\text { PC }\end{array}$ \\
\hline $\begin{array}{l}\text { (Williams, } \\
\text { 2010) }\end{array}$ & $32.3 \%$ & $0.5 \%$ & $1.8 \%$ & $0.3 \%$ & $*$ & $0.1 \%$ & $0.7 \%$ & * & * & 140 & $*$ & * & * & $*$ & * & 30 & 4,120 & Pyrolysis & ICP & 2010 & $\begin{array}{c}\text { PCB - } \\
\text { m. } \\
\text { phone }\end{array}$ \\
\hline Source & $\mathrm{Cu}$ & $\mathrm{Fe}$ & Al & $\mathrm{Pb}$ & Sn & $\mathrm{Zn}$ & $\mathrm{Ni}$ & $\mathrm{Ba}$ & $\mathrm{Bi}$ & $\mathrm{Cr}$ & Co & $M n$ & $\mathrm{Sb}$ & $\mathrm{Ti}$ & $P d$ & $\mathrm{Au}$ & Ag & $\begin{array}{c}\text { Sample } \\
\text { preparation }\end{array}$ & Method & Year & $\begin{array}{c}\text { Type of } \\
\text { PCB }\end{array}$ \\
\hline $\begin{array}{c}\text { (Oguchi et al., } \\
\text { 2011) }\end{array}$ & $20.0 \%$ & $1.3 \%$ & $1.8 \%$ & $2.3 \%$ & $1.8 \%$ & $0.3 \%$ & $*$ & 1,900 & 50 & $*$ & 48 & $*$ & $*$ & $*$ & 150 & 240 & 570 & Aqua regia & $\begin{array}{l}\text { ICP-OES } \\
\text { / MS }\end{array}$ & 2011 & PCB - PC \\
\hline $\begin{array}{c}\text { (Oguchi et al., } \\
\text { 2011) } \\
\end{array}$ & $33.0 \%$ & $1.8 \%$ & $1.5 \%$ & $1.3 \%$ & $3.5 \%$ & $0.5 \%$ & $*$ & 19,000 & 440 & $*$ & 280 & $*$ & $*$ & $*$ & 300 & 1,500 & 3,800 & Aqua regia & $\begin{array}{l}\text { ICP-OES } \\
\text { / MS }\end{array}$ & 2011 & $\begin{array}{l}\mathrm{PCB}-\mathrm{m} . \\
\text { phone }\end{array}$ \\
\hline $\begin{array}{c}\text { (Yamane et al., } \\
\text { 2011) }\end{array}$ & $20.2 \%$ & $7.3 \%$ & $5.7 \%$ & $5.5 \%$ & $8.8 \%$ & $4.5 \%$ & $0.4 \%$ & $*$ & $*$ & $*$ & $*$ & $*$ & $*$ & $*$ & $*$ & 1,300 & 1,600 & Aqua regia & ICP-OES & 2011 & PCB - PC \\
\hline $\begin{array}{c}\text { (Yang et al., } \\
\text { 2011) }\end{array}$ & $25.3 \%$ & $0.2 \%$ & $*$ & $0.1 \%$ & $0.3 \%$ & $*$ & $0.0 \%$ & $*$ & $*$ & 24 & $*$ & $*$ & $*$ & $*$ & $\mathrm{BDI}$ & 105 & 107 & Aqua regia & $\mathrm{ICP}$ & 2011 & $P C B-\operatorname{mix}$ \\
\hline $\begin{array}{c}\text { (Birloaga et al., } \\
\text { 2013) }\end{array}$ & $31.8 \%$ & $13.8 \%$ & $10.5 \%$ & $4.9 \%$ & $7.0 \%$ & $2.2 \%$ & $2.0 \%$ & $*$ & $*$ & $*$ & $*$ & $*$ & $*$ & $*$ & $*$ & 369 & 689 & Aqua regia & XRF & 2013 & PCB - mix \\
\hline (Le et al., 2013) & $38.9 \%$ & $10.8 \%$ & $1.0 \%$ & $1.7 \%$ & $2.5 \%$ & $0.3 \%$ & $1.7 \%$ & $*$ & $*$ & $*$ & 1,700 & $*$ & 400 & $*$ & 142 & 1,645 & 3,985 & N/A & $\mathrm{N} / \mathrm{A}$ & 2013 & PCB - mix \\
\hline $\begin{array}{c}\text { (Ortuño et al., } \\
2013)\end{array}$ & $24.2 \%$ & $0.2 \%$ & $3.3 \%$ & $0.9 \%$ & $1.4 \%$ & $0.1 \%$ & $0.3 \%$ & $*$ & $*$ & $*$ & $*$ & $*$ & $*$ & $*$ & $*$ & 600 & 1,000 & Aqua regia & XRF & 2013 & $\begin{array}{c}\mathrm{PCB}-\mathrm{m} . \\
\text { phone }\end{array}$ \\
\hline $\begin{array}{c}\text { (Behnamfard et } \\
\text { al., 2013) }\end{array}$ & $19.2 \%$ & $1.1 \%$ & $4.0 \%$ & $0.4 \%$ & $0.7 \%$ & $0.8 \%$ & $0.2 \%$ & 0.361 & $*$ & 0.118 & $*$ & 0.035 & $*$ & 0.176 & 27 & 130 & 704 & N/A & $\mathrm{XRF} / \mathrm{ICP}$ & 2013 & PCB - PC \\
\hline $\begin{array}{c}\text { (Yazici and } \\
\text { Deveci, 2013) }\end{array}$ & $18.5 \%$ & $2.1 \%$ & $1.3 \%$ & $2.7 \%$ & $4.9 \%$ & $*$ & $0.4 \%$ & $*$ & $*$ & $*$ & $*$ & $*$ & $*$ & $*$ & 97 & 86 & 694 & Aqua regia & $\mathrm{ICP}$ & 2013 & $P C B-P C$ \\
\hline $\begin{array}{c}\text { (Evangelopoulos } \\
\text { et al., 2015) }\end{array}$ & $30.6 \%$ & $15.2 \%$ & $11.7 \%$ & $6.7 \%$ & $7.4 \%$ & $1.9 \%$ & $1.6 \%$ & $*$ & * & * & $*$ & $*$ & $*$ & * & $*$ & 238 & 688 & Thiourea & XRF & 2014 & $\begin{array}{l}\text { PCB - mix } \\
\text { (stripped) }\end{array}$ \\
\hline
\end{tabular}




\begin{tabular}{|c|c|c|c|c|c|c|c|c|c|c|c|c|c|c|c|c|c|c|c|c|c|}
\hline $\begin{array}{c}\text { (Yang et al., } \\
\text { 2014) }\end{array}$ & $25.5 \%$ & $3.2 \%$ & $6.3 \%$ & $2.3 \%$ & $3.3 \%$ & $6.2 \%$ & $0.5 \%$ & 4,540 & $*$ & $*$ & $*$ & 1,620 & $*$ & $*$ & $*$ & $*$ & $*$ & Aqua regia & ICP-OES & 2014 & PCB - PC \\
\hline $\begin{array}{l}\text { (Fujita et al., } \\
\text { 2014) }\end{array}$ & $15.0 \%$ & $2.5 \%$ & $4.0 \%$ & $2.0 \%$ & $*$ & $*$ & $0.5 \%$ & $*$ & $*$ & 760 & 62 & 614 & $*$ & 1,000 & 90 & 320 & 1,200 & N/A & $*$ & 2014 & PCB - mix \\
\hline $\begin{array}{c}\text { (Camelino et al., } \\
\text { 2015) }\end{array}$ & $65.7 \%$ & $1.5 \%$ & $*$ & $1.1 \%$ & $5.2 \%$ & $0.2 \%$ & $2.0 \%$ & $*$ & $*$ & $*$ & $*$ & $*$ & $*$ & $*$ & 110 & 168 & 285 & Aqua regia & ICP & 2015 & PCB - mix \\
\hline $\begin{array}{c}\text { (Birloaga et al., } \\
\text { 2013) }\end{array}$ & $33.9 \%$ & $1.0 \%$ & $2.6 \%$ & $5.0 \%$ & $*$ & $0.9 \%$ & $0.1 \%$ & 1,645 & & 327 & 3 & 78 & 40.8 & 1,372 & 12 & 7 & 398 & Pyrolysis & ICP & 2015 & $\begin{array}{l}\text { PCB - mix } \\
\text { (stripped) }\end{array}$ \\
\hline (Xiu et al., 2015) & $40.8 \%$ & $0.3 \%$ & $*$ & $1.4 \%$ & $1.6 \%$ & $0.4 \%$ & $0.4 \%$ & $*$ & $*$ & $*$ & $*$ & $*$ & $*$ & $*$ & 50 & 65 & 1,060 & $\mathrm{~N} / \mathrm{A}$ & ICP-OES & 2015 & $\begin{array}{l}\text { PCB - mix } \\
\text { (stripped) }\end{array}$ \\
\hline $\begin{array}{c}\text { (Chen et al., } \\
\text { 2015) }\end{array}$ & $24.8 \%$ & $0.2 \%$ & $2.5 \%$ & $0.6 \%$ & $*$ & $*$ & $*$ & $*$ & $*$ & $*$ & $*$ & $*$ & $*$ & * & $*$ & $*$ & * & Aqua regia & ICP-OES & 2015 & PCB - mix \\
\hline $\begin{array}{c}\text { (Zhang et al., } \\
\text { 2016b) }\end{array}$ & $30.9 \%$ & $4.1 \%$ & $*$ & $2.1 \%$ & $*$ & $0.4 \%$ & $0.4 \%$ & $*$ & $*$ & $*$ & $*$ & 1 & $*$ & $*$ & 435 & 385 & 754 & Thiourea & ICP & 2016 & $\begin{array}{r}\text { PCB - PC } \\
\text { (stripped) } \\
\end{array}$ \\
\hline $\begin{array}{c}\text { (Zhang et al., } \\
\text { 2016a) }\end{array}$ & $29.9 \%$ & $7.8 \%$ & $12.2 \%$ & $3.9 \%$ & $5.3 \%$ & $0.3 \%$ & $*$ & 8,100 & $*$ & $*$ & * & 12,100 & 15,000 & 12,100 & $*$ & * & $*$ & Pyrolysis & XRF & 2016 & PCB - mix \\
\hline $\begin{array}{l}\text { (Evangelopoulos } \\
\text { et al., 2017) }\end{array}$ & $17.7 \%$ & $5.2 \%$ & $3.6 \%$ & $0.9 \%$ & $*$ & $0.5 \%$ & $0.3 \%$ & $*$ & $*$ & 290 & $*$ & $*$ & $*$ & $*$ & $*$ & 21 & $*$ & Aqua regia & AAS & 2016 & PCB-PC \\
\hline $\begin{array}{l}\text { (Evangelopoulos } \\
\text { et al., 2017) }\end{array}$ & $23.0 \%$ & $3.8 \%$ & $1.0 \%$ & $0.1 \%$ & $*$ & $0.3 \%$ & $1.2 \%$ & $*$ & $*$ & 2,000 & * & $*$ & $*$ & $*$ & $*$ & 320 & $*$ & Aqua regia & AAS & 2016 & $\begin{array}{l}\mathrm{PCB}-\mathrm{m} . \\
\text { phone }\end{array}$ \\
\hline $\begin{array}{l}\text { (Neto et al., } \\
\text { 2016) }\end{array}$ & $14.7 \%$ & $3.3 \%$ & $5.9 \%$ & $2.4 \%$ & $0.8 \%$ & $0.3 \%$ & $0.5 \%$ & $*$ & $*$ & $*$ & * & $*$ & $*$ & $*$ & $*$ & 510 & 440 & $\mathrm{~N} / \mathrm{A}$ & $*$ & 2016 & PCB - mix \\
\hline $\begin{array}{c}\text { (Işıldar et al., } \\
\text { 2016) }\end{array}$ & $33.9 \%$ & $1.0 \%$ & $2.6 \%$ & $5.0 \%$ & $0.2 \%$ & $0.9 \%$ & $0.1 \%$ & 1,645 & $*$ & 237 & $*$ & $*$ & 41 & 1,372 & 12 & 7 & 398 & $*$ & TGA & 2017 & PCB - PC \\
\hline
\end{tabular}

